Research Article

\title{
A Study to Evaluate Therapeutic Management of Various Cutaneous Disorders in Diabetic Patients
}

\author{
A.Bharath ${ }^{1 *}$, G. Madhuri ${ }^{1}$, Dr.R.E.Ugandar ${ }^{2}$, Dr.M.Madhavi latha ${ }^{3}$ \\ 1,Pharm.D , Santhiram College of Pharmacy, Nandyal, AP, India. \\ 2. Department of Pharmaceutical sciences, Santhiram College of Pharmacy, Nandyal, AP, India. \\ 3. Department of Dermatology, Santhiram Medical College, Nandyal, Ap, India. \\ *Corresponding author's E-mail: bharath240897@gmail.com
}

Received: 05-01-2021; Revised: 22-02-2021; Accepted: 28-02-2021; Published on: 20-03-2021.

\begin{abstract}
Diabetes Mellitus represent an area in which cutaneous manifestations are considered as important clues towards diagnosis as the patients are more susceptible to a number of muco-cutaneous disorders. The study was carried out to assess various cutaneous manifestations in diabetic patients, their therapeutic management and clinical outcomes. A prospective study was undertaken in which diabetic patients with cutaneous disorders were selected. After clinical assessment of their conditions, they were therapeutically managed and their outcomes were measured, relevant patient counselling was done along with the provided leaflets. About 150 patients of various skin disorders were included in the study. The pattern of cutaneous manifestations found were as follows: Cutaneous infections were observed in 85 patients in which fungal infections were more predominant affecting $52.2 \%$ of patients, followed by Dermatoses commonly associated with DM were observed in 38 patients, Non-specific manifestations were seen in 14 patients and neuropathic and ischemic skin diseases were seen in 38 patients. Among which Tinea corporis was most predominant cutaneous manifestation and icthyosis was the least commonly predominant manifestation among all the skin conditions. Male diabetic patients were more prone to infections than females. All the skin conditions were therapeutically managed. Maintaining appropriate glycaemic control in diabetic patients can reduce these infections. Education of patients and health care personnel regarding adaptation of preventive measures, life style modifications and seeking timely dermatological opinion for these skin problems may reduce morbidity, complications, hospital visits and burden on health care facilities. Among 150 cases collected, 108 patients which was $87.1 \%$ of total including both diabetes and cutaneous conditions were observed as improved. In 48 patients which was $12.8 \%$ of the total, the conditions were found to be stable without any adverse effects or complications as a result of given treatment and effective patient counselling towards their life style modifications.
\end{abstract}

Keywords: Cutaneous manifestations, Diabetes mellitus, Management, RBS levels, Patient Counselling.

QUICK RESPONSE CODE $\rightarrow$

DOI:

10.47583/ijpsrr.2021.v67i01.025

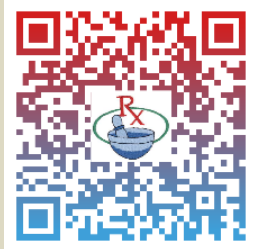

DOI link: $\underline{\text { http://dx.doi.org/10.47583/ijpsrr.2021.v67i01.025 }}$

\section{INTRODUCTION}

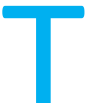

he skin is the outer covering of the body and is the largest organ, it is affected by both acute metabolic dearrangements and chronic degenerative complications of diabetes mellitus. Individuals with type 2 Diabetes mellitus are more likely than those with type 1 diabetes to develop cutaneous manifestations.

The cutaneous disease can appear as the first sign of diabetes (or) may develop at any time in the course of the disease. Skin can show signs of an internal disease in some cases before the disease advances and becomes more serious. In other cases, symptoms appear on the skin long after the disease begins causing internal damage. Some of the skin changes which may indicate internal diseases like a new rash, change in texture (or) colour, the appearance of growth, etc.,.
The skin changes may eventually be used as a reflection of the patient's current as well as past metabolic status. Endocrine diseases, particularly Diabetes mellitus, represent an area in which cutaneous manifestations may be important clues to the diagnosis. Patients with endocrine diseases are especially susceptible to a number of associated mucocutaneous disorders. Diabetes mellitus is a very common medical disease with sequelae that affect almost every organ system, especially the skin is no exception. The pandemic growth of Diabetes mellitus is by demographics (population, aging), socioeconomic, migratory, nutritional, lifestyle patterns and over-weight. The manifestations of Diabetes mellitus of the integument are numerous and varied. There is considerable uncertainty about the pathogenesis of many of the cutaneous conditions affecting Diabetics. The main mechanism behind all these changes is thought to be nonenzymatic glycosylation end product formation. This process occurs to a minor extent at normal blood sugar concentrations and is apparently accelerated in patients with increased blood glucose levels. This reaction results in changes in the physical and chemical properties of connective tissues and other body proteins, these modified proteins and glycosylation end products are responsible for various skin complications seen in DM. 
Many Cutaneous signs are readily recognizable as Diabetic Markers like diabetic dermopathy, diabetic bullae, waxy skin syndrome which are virtually diagnostic of Diabetes mellitus. Some cutaneous conditions appear to be caused by the primary abnormalities of Diabetes mellitus or by major complications, Vasculopathy, and neuropathy, others are linked to altered immunologic conditions, to changes in collagen, and some are a consequence of treatment.

Dermatologic disorders associated with Diabetes mellitus generally appear after the primary disease or they may signal or appear after the primary disease or they may signal or appear coincidentally with its onset, or even precede Diabetes mellitus by many years. The cutaneous clinical signs are numerous and varied as $1 / 3^{\text {rd }}$ of patients with Diabetes mellitus are estimated to have cutaneous changes.

\section{METHODS}

\section{Ethical consideration}

The protocol of the study was approved by the institutional ethics committee of Santhiram medical college and general hospital, Nandyal. The study was conducted in compliance with good clinical practice guidelines.

\section{Study design}

It is a prospective study which includes diabetic patients with cutaneous manifestations from Inpatient and Outpatient units of dermatology department in Santhiram Medical College and General Hospital to study pattern of cutaneous manifestations, their severity, therapeutic management in diabetic patients and providing leaflets as a part of patient counselling.

\section{Study Site}

Department of Dermatology, Santhiram Medical College and General Hospital, Nandyal, tertiary care teaching hospital with approximately 700 bedded capacities.

\section{Study Population}

All the diabetic patients with cutaneous manifestations from Inpatient and Outpatient units of dermatology department of Santhiram Medical College and General Hospital, Nandyal.

\section{Sample Size}

$>150$ patients.

\section{SAMPLING CRITERIA:}

$>$ INCLUSION CRITERIA:

- Patients with informed consent form.

- Diabetic patients with cutaneous disorders.

- Patients with age above 20 years.

- Patients with suspected cutaneous symptoms.

> EXCLUSION CRITERIA:

- Participants who are unwilling to join the study

- Pregnant women

Statistics:

- Population: Diabetic patients with cutaneous manifestations were selected.

- Method of selecting the sample: Dermatology and General Medicine OP and IP department.

- Subjects are allocated based on type of cutaneous condition.

- $\quad$ Statistical method: Paired $t^{\prime}$ test.

\section{Paired t test}

\begin{tabular}{|c|c|c|}
\hline Test & Tabular $p$-value & Outcome $p$-value \\
\hline Paired t test & $<0.05$ & $<0.00001$ \\
\hline
\end{tabular}

$P$ tabular value $=0.05$;

As $P$ calculated value is less than tabular value $(0.00001<0.05)$

Hence there is significant relation between RBS levels before and after treatment and patient counselling.

\section{Study Period}

6 months

RESULTS

Table I: Age wise gender distribution

\begin{tabular}{|c|c|c|c|c|}
\hline Age (in years) & Males $(\mathbf{n})$ & Females $(\mathbf{n})$ & Total $(\mathbf{n})$ & Percentage (\%) \\
\hline $21-40$ & 15 & 28 & 43 & 28.6 \\
\hline $41-60$ & 52 & 19 & 71 & 47.3 \\
\hline $61-80$ & 29 & 7 & 36 & 24.0 \\
\hline Total & 96 & 54 & 150 & 100 \\
\hline
\end{tabular}




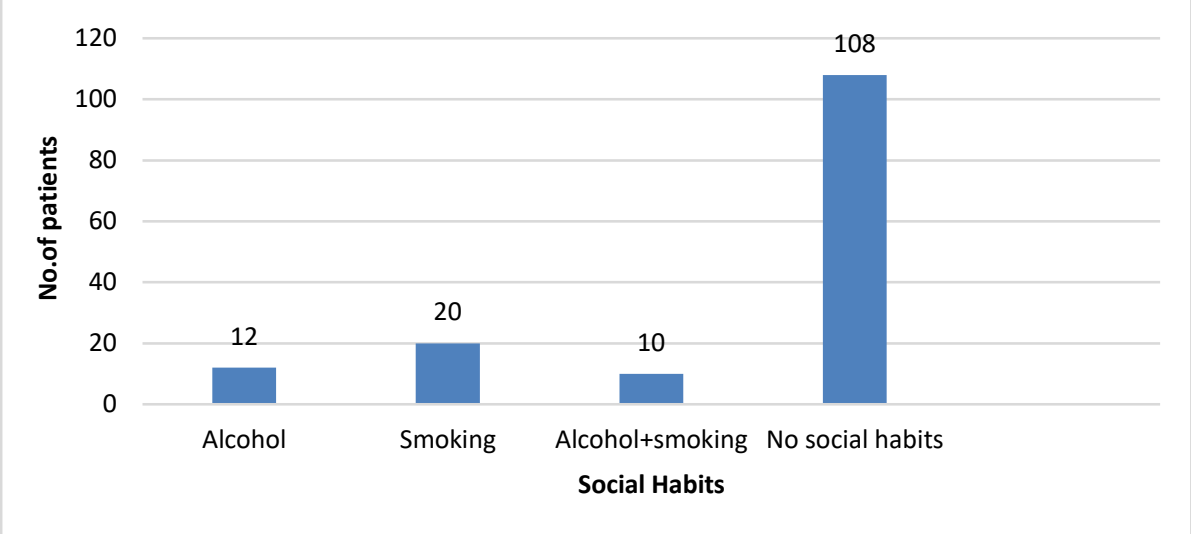

Figure 1: Social history of the patients

Table II: Duration of diabetes

\begin{tabular}{|c|c|c|}
\hline $\begin{array}{c}\text { Duration } \\
\text { (years) }\end{array}$ & No. of patients & Percentage(\%) \\
\hline$<1$ & 31 & 20.6 \\
\hline $1-5$ & 65 & 43.3 \\
\hline $6-10$ & 34 & 22.6 \\
\hline$>10$ & 20 & 13.3 \\
\hline
\end{tabular}

Table III: Distribution of patients based on RBS levels (before treatment)

\begin{tabular}{|c|c|c|}
\hline RBS level (mg/dl) & Total (150) & Percentage (\%) \\
\hline $180-250$ & 106 & 71 \\
\hline $251-300$ & 36 & 24 \\
\hline $301-350$ & 8 & 5 \\
\hline
\end{tabular}

Table IV: Cutaneous manifestations in diabetes mellitus

\section{Cutaneous manifestations}

\section{Percentage}

1.Cutaneous infections

a. Bacterial-i. cellulitis

ii. furunclulosis

iii. folliculitis

iv. erysipelas

v. carbuncle

b. fungal - i. tinea corporis

ii. tinea cruris

iii. Pityriasis versicolor

iv. Vulvovaginal candidiosis

c. viral - herpes zoster

2. Neuropathic and ischemic skin disease
a. diabetic foot ulcer
8
b. gangrene
5

3. manifestations commonly associated with DM
a. generalized pruritus
b. psoriasis
6
c. Vitiligo
4
d. acanthosis nigricans
2
e. lichen planus

18

8

4. non-specific manifestations
a. eczema
b. xerosis
2
c. scabies
4
d. icthyosis

18

6

4

3

2

19

22

2

4

5

8


Table V: Percentage distribution of patients with severity in RBS and Cutaneous manifestations

\begin{tabular}{l|ll} 
Disease & Patients (\%) & RBS elevation (avg. units) Severity
\end{tabular}

\section{Cellulitis}

Diabetic foot

Generalised pruritus

Lichen planus

Tinea corporis Tinea cruris

Furuncle

Folliculitis

Erysipelas

Carbuncle

Eczema

Icthyosis

Xerosis

Scabies

Vitiligo

Psoriasis

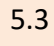

11.3

9.3

10.6

13.3

10

4.6

2

2.6

2.6

4
79

84

66

40

79

49

38

44

52

48

59
Redness, purulent discharge, swelling, high fever.

Swelling, fever, redness.

Itching, redness, rash, blisters.

Purplish lesions or bumps, loss of colour.

Itching, circular rash, scaly skin.

Red lesions, fever, pus filled blisters, pain, burning sensation, redness.

Dry skin, scaly skin, inflammation, itching, oozing.

Dry, itchy, scaly skin, cracks on the skin.

Bumps, redness, itching, skin burrows. Loss of skin colour in patches (depigmentation)

Red, raised, inflamed patches on the skin, dry skin, pain.

Table VI: Distribution of patients based on drugs Prescribed

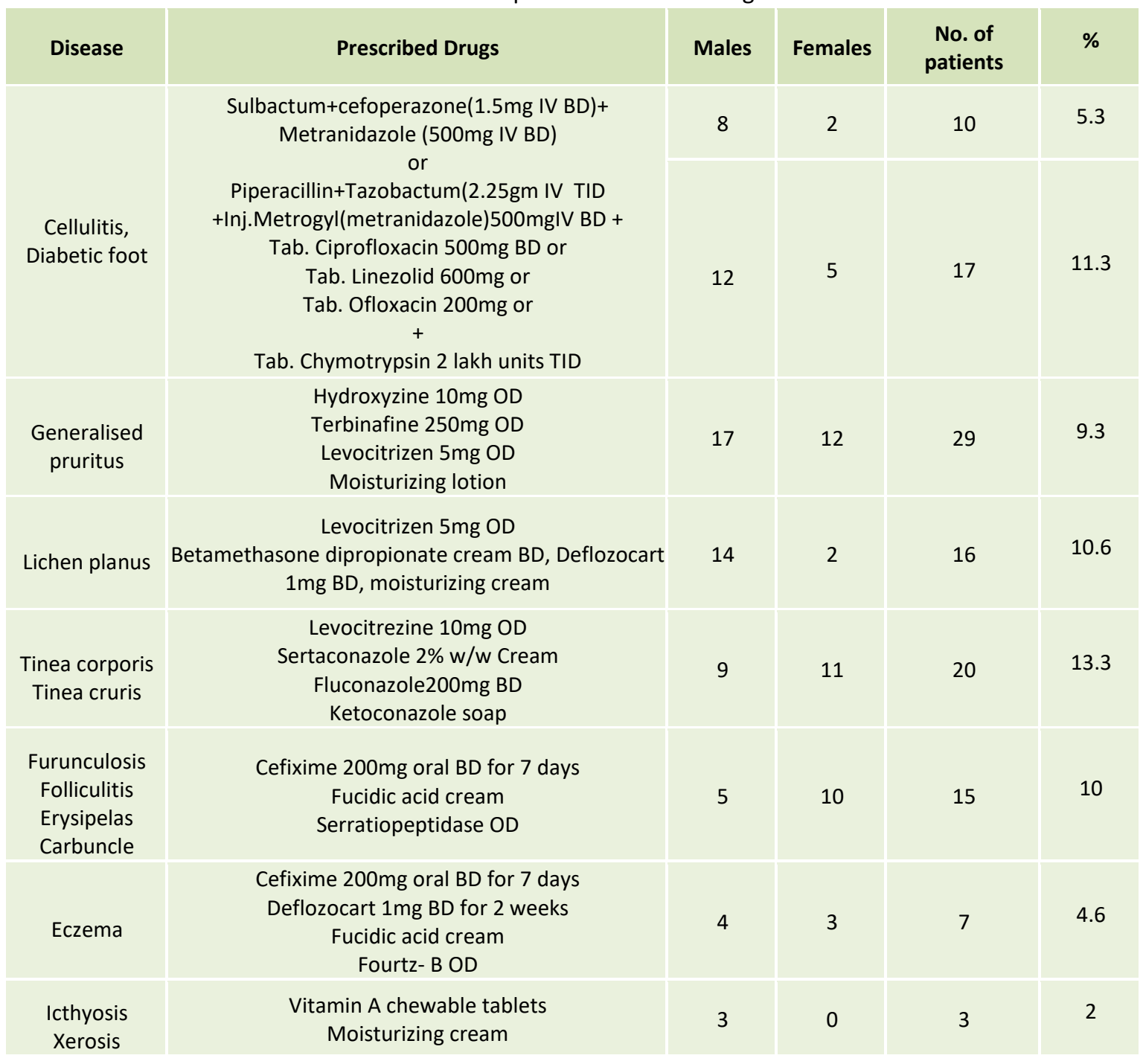




\begin{tabular}{|c|c|c|c|c|c|}
\hline Scabies & $\begin{array}{c}\text { Permethrin lotion once per week } 2 \text { times } \\
\text { Hydroxyzine } 10 \mathrm{mg}\end{array}$ & 3 & 1 & 4 & 2.6 \\
\hline Vitiligo & $\begin{array}{c}\text { Betamethasone } 1 \mathrm{mg} \text { twice weekly } \\
\text { Levamisole } 150 \mathrm{mg} \text { twice weekly } \\
\text { Tacrolimus } 0.1 \% \mathrm{w} / \mathrm{v} \text { BD }\end{array}$ & 2 & 2 & 4 & 2.6 \\
\hline Psoriasis & $\begin{array}{c}\text { Omega-3 fatty acid OD } \\
\text { Hydroxyzine } 10 \mathrm{mg} \\
\text { Moisturizing lotion BD } \\
\text { Clobetasol propionate } 0.05 \% \mathrm{w} / \mathrm{v}+ \\
\text { Salicylic acid } 3 \% \mathrm{w} / \mathrm{v}\end{array}$ & 4 & 2 & 6 & 4 \\
\hline
\end{tabular}

Table VII: RBS levels after treatment and patient

\begin{tabular}{|c|c|c|}
\hline \multicolumn{3}{|c|}{ counselling } \\
\hline RBS Levels & Total (150) & Percentage (\%) \\
\hline$<180$ & 124 & 82.6 \\
\hline $180-200$ & 24 & 16 \\
\hline $200-250$ & 2 & 1.3 \\
\hline
\end{tabular}

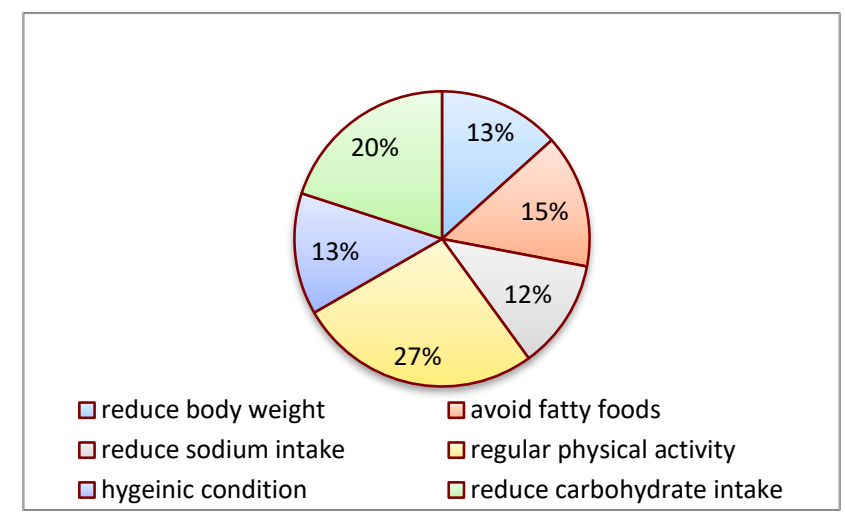

Figure 2: Pie diagram of patient counselling

Table VIII: Percentage distribution of patients with severity in RBS and Cutaneous manifestations after treatment and counselling

\begin{tabular}{|c|c|c|c|c|}
\hline Disease & $\begin{array}{c}\text { No. of } \\
\text { patients (\%) }\end{array}$ & $\begin{array}{l}\text { RBS elevation } \\
\text { (avg units) }\end{array}$ & Severity & Outcomes \\
\hline Cellulitis & 5.3 & 20 & $\begin{array}{l}\text { Decreased Redness, purulent } \\
\text { discharge, swelling, high fever. }\end{array}$ & Stable \\
\hline Diabetic foot & 11.3 & 41 & Reduced Swelling, fever, redness. & Stable \\
\hline Generalised pruritus & 9.3 & 30 & No Itching, redness, rash, blisters. & Improved \\
\hline Lichen planus & 10.6 & 15 & $\begin{array}{l}\text { Reduced Purplish lesions or } \\
\text { bumps, loss of colour. }\end{array}$ & Improved \\
\hline $\begin{array}{l}\text { Tinea corporis } \\
\text { Tinea cruris }\end{array}$ & 13.3 & 28 & $\begin{array}{c}\text { Decreased Itching, circular rash, } \\
\text { scaly skin. }\end{array}$ & Improved \\
\hline $\begin{array}{l}\text { Furuncle } \\
\text { Folliculitis } \\
\text { Erysipelas } \\
\text { Carbuncle }\end{array}$ & 10 & 15 & $\begin{array}{l}\text { Decreased Red lesions, fever, pus } \\
\text { filled blisters, pain, burning } \\
\text { sensation, redness. }\end{array}$ & Improved \\
\hline Eczema & 4.6 & 10 & $\begin{array}{l}\text { Decreased dry skin, scaly skin, } \\
\text { inflammation, itching, oozing. }\end{array}$ & Improved \\
\hline $\begin{array}{l}\text { Icthyosis } \\
\text { Xerosis }\end{array}$ & 2 & 9 & $\begin{array}{l}\text { Reduced dry, itchy, scaly skin, } \\
\text { cracks on the skin. }\end{array}$ & Improved \\
\hline Scabies & 2.6 & 10 & $\begin{array}{l}\text { Decreased bumps, redness, } \\
\text { itching, skin burrows. }\end{array}$ & Improved \\
\hline Vitiligo & 2.6 & 15 & $\begin{array}{l}\text { Depigmented patches start } \\
\text { disappearing }\end{array}$ & Stable \\
\hline Psoriasis & 4 & 20 & $\begin{array}{c}\text { Reduced red, raised, inflamed } \\
\text { patches on the skin, dry skin and } \\
\text { pain. }\end{array}$ & Stable \\
\hline
\end{tabular}

\section{DISCUSSION}

A number of dermatological conditions are associated with or a sequelae of diabetes mellitus. Many of the conditions are due to high prevalence of diabetes in the general population. A large number of the dermatological problems in diabetics are caused by hyperglycemia induced accelerated production of non-enzymatic advanced glycosylated end products.
About $30 \%$ of diabetic patients have some cutaneous involvement during the course of their disease. In our study most of the diabetics had some kind of skin lesions attributed to diabetics, which indicates a high incidence of cutaneous involvement. 56.6 percent patients had cutaneous infections. The diabetic state decreases the resistance of host to infection by impairing many functions of the neutrophils. These infections are 
probably more frequent in patients with poor controlled disease.

This study included 150 patients of diabetes mellitus with cutaneous manifestations who attended dermatology department of a tertiary care teaching hospital.

Increasing duration of diabetes increases the possibility of skin involvement, impaired diabetic control as evidenced by higher HbA1C levels was found among patients with infections ( Nandini Chatterjee, et al., 2019). In our study RBS levels are found increased due to impaired diabetic control in patients with infections and the patients with $>10$ years of diabetic duration has more involvement of skin.

The impact of Duration of diabetes was observed to be more in 65 patients who are suffering with diabetes mellitus from 1 to 5 years and 20 patients with duration more than 10 years.

Most of the diabetic patients who developed cutaneous manifestations were in the 40-60 years age group ( Nawaf Al-Mutairi, et al., 2006). In our study the age group of 40 60 years $(47.3 \%)$ are mostly developed skin infections. Among 150 patients involved, the females of age group 21-40 are mostly affected with cutaneous infections with mild stage condition. In females stress, illness, occupation, high blood sugar levels will increase development of infections more quickly. Whereas males of age group 4180 are mostly affected due to age factor (as age increases, immunity decreases), social habits (alcohol, smoking), occupation and any co-morbid conditions. The occurrence of cutaneous infections in male patients were observed due to these conditions.

The most common systemic complication of diabetes was hypertension (Nawafal-Mutairi, et al., 2006). In our study the most common complication was obesity is seen among $34.6 \%$ of patients followed by hypertension among $14 \%$ of patients.

From the obtained data, it has been observed that 108 patients who do not have any social habits were reported with diabetes associated cutaneous disorders. The impact of social habits on the diabetes associated cutaneous disorders was observed to be very nominal in the whole group.

Among 150 patients, $87.1 \%$ condition got improved and $12.8 \%$ condition got stable after therapy and appropriate patient counselling.

Patient counselling is done according to the type of skin problems and existing co-morbid conditions. By effective counselling, complications and number of hospital visits can be reduced. There by patient quality of life is increased.

\section{CONCLUSION}

This Prospective observational study was conducted in the department of Dermatology, Santhiram General Hospital \& Medical College, Nandyal. A total number of 150 subjects, all aged above 20 years were included in the study. This study has provided some insight into the pattern of cutaneous manifestations of diabetes mellitus, and its complications which are frequently occurred in diabetes due to poor glycemic control with longer duration and associated with HTN, obesity and CVD. The management of diabetes is a holistic one and that should focus due attention on skin complications.

Our study results revealed that male diabetic patients were more predominant to cutaneous infections than female diabetic patients due to their social habits, occupation, co-morbid conditions, and age factors. Among 150 cases collected, 108 patients which was $87.1 \%$ of total including both diabetes and cutaneous conditions were observed as improved. In 48 patients which was $12.8 \%$ of the total, the conditions were found to be stable without any adverse effects or complications as a result of given treatment and effective patient counselling towards their life style modifications.

Maintaining appropriate glycemic control in diabetic patients can reduce these infections. Education of patients and health care personnel regarding adaptation of preventive measures, life style modifications and seeking timely dermatological opinion for these skin problems may reduce morbidity, complications, hospital visits and burden on health care facilities. Pharmacist can play the major role in improving the patient care by the counselling and advising about the medications and life style modifications in the initial stages may contribute to the health of the patient. It shows the positive impact on pharmacist intervention towards the patient disease management especially in cutaneous manifestations associated with Diabetes Mellitus.

\section{REFERENCES}

1. Ahmed K, Muhammad Z, Qayum I. Prevalence of cutaneous manifestations of diabetes mellitus. J Ayub Med Coll Abbottabad. 2009 Jun $1 ; 21(2)$ : 76-9.

2. Al-Mutairi N, Zaki A, Sharma AK, Al-Sheltawi M. Cutaneous manifestations of diabetes mellitus. Medical Principles and Practice. 2006;1 5(6): 427-30.

3. American Diabetes Association. 4. Lifestyle management. Diabetes Care. 2017 Jan 1;40(Supplement 1): S33-43.

4. Bhat YJ, Gupta V, Kudyar RP. Cutaneous manifestations of diabetes mellitus. Int J Diab Dev Ctries. 2006 Dec; 26(4): 153

5. Bustan RS, Wasim D, Yderstræde KB, Bygum A. Specific skin signs as a cutaneous marker of diabetes mellitus and the prediabetic state-a systematic review. Dan Med J. 2017 Jan 1; 64(1): A5316.

6. Casqueiro J, Casqueiro J, Alves C. Infections in patients with diabetes mellitus: A review of pathogenesis. Indian journal of endocrinology and metabolism. 2012 Mar; 16(Suppl1): S27.

7. Chatterjee N, Chattopadhyay C, Sengupta N, Das C, Sarma N, Pal SK. An observational study of cutaneous manifestations in diabetes mellitus in a tertiary care Hospital of Eastern India. Indian journal of endocrinology and metabolism. 2014 Mar; 18(2): 217.

8. DAY NO. Lifestyle Changes to Manage Type 2 Diabetes. Am Fam Physician. 2009 Jan 1; 79(1): 42. 
9. de Macedo GM, Nunes S, Barreto T. Skin disorders in diabetes mellitus: an epidemiology and physiopathology review. Diabetology \& metabolic syndrome. 2016 Dec 1; 8(1): 63.

10. Duff M, Demidova O, Blackburn S, Shubrook J. Cutaneous manifestations of diabetes mellitus. Clinical Diabetes. 2015 Jan 1; 33(1): 40-8

11. Farshchian M, Fereydoonnejad M, Yazdanfar A, Kimyai-Asadi A. CUTIS Do Not Copy. Cutis. 2010; 86: 31-5.

12. Ferringer T, Miller OF. Cutaneous manifestations of diabetes mellitus. Dermatologic clinics. 2002 Jul 1; 20(3): 483-92.

13. Gangawane AK, Bhatt B, Sunmeet M. Skin infections in diabetes: a review. J Diabetes Metab. 2016 Feb 1; 7(2): 1-4.

14. Ghosh K, Das K, Ghosh S, Chakraborty S, Jatua SK, Bhattacharya A, Ghosh M. Prevalence of skin changes in diabetes mellitus and its correlation with internal diseases: A single center observational study. Indian journal of dermatology. 2015 Sep; 60(5): 465.

15. Gkogkolou P, Böhm M. Skin disorders in diabetes mellitus. JDDG: Journal der Deutschen Dermatologischen Gesellschaft. 2014 Oct; 12(10): 847-64.

16. Goyal A, Raina S, Kaushal SS, Mahajan V, Sharma NL. Pattern of cutaneous manifestations in diabetes mellitus. Indian journal of dermatology. 2010 Jan; 55(1): 39.

17. Jellinek N. Manual of dermatologic therapeutics. Kenneth A. Arndt and Kathryn E. Bowers, Philadelphia, 2002, Lippincott Williams \& Wilkins. 401 pages. \$39.95. ISBN: 0-78172-170-9. Journal of the American Academy of Dermatology. 2003 Dec 1; 49(6): 1207.

18. Kameti S, AL SK, Reddy P, Aruna C. Spectrum of cutaneous manifestations in diabetes mellitus and their association with duration of diabetes mellitus: An observational study in a tertiary care hospital of South India. Journal of Pakistan Association of Dermatology. 2018 Mar 15; 27(3): 252-8.

19. Kataria U, Chhillar D, Kumar H, Chhikara P. Cutaneous manifestations of diabetes mellitus in controlled and uncontrolled state. Int Arch Integr Med. 2015; 2: 90-3.

20. Kumar AA, Ansari SH, Gupta V. A Study on Cutaneous Manifestations in Patients of Type 2 Diabetes Mellitus in a Tertiary Care Hospital. Int J Med Res Prof. 2016; 2(1): 125-7.

21. Mahajan S, Koranne RV, Sharma SK. Cutaneous manifestation of diabetes melitus. Indian Journal of Dermatology, Venereology, and Leprology. 2003 Jan 3; 69(2): 105.

22. Mahmood T, ul Bari A, Agha H. Cutaneous manifestations of diabetes mellitus. Journal of Pakistan Association of Dermatology. 2016 Dec 28; 15(3): 227-32.

23. Mendes AL, Miot HA, Haddad Junior V. Diabetes mellitus and the skin. Anais brasileiros de dermatologia. 2017 Feb; 92(1): 8-20.

24. Nern K. Dermatologic conditions associated with diabetes. Current diabetes reports. 2002 Jan 1; 2(1): 53-9.

25. Niaz F, Bashir F, Shams N, Shaikh Z, Ahmed I. Cutaneous manifestations of diabetes mellitus type 2: prevalence and association with glycemic control. Journal of Pakistan Association of Dermatology. 2016 Nov 18; 26(1): 4-11.
26. Pandey S, Mishra P, Sharma N, Shyam BK. Dermatological Manifestations in Diabetes Mellitus at NGMCTH Kohalpur. Journal of Nepalgunj Medical College. 2015; 13(2): 31-4.

27. Papatheodorou K, Banach M, Bekiari E, Rizzo M, Edmonds M. Complications of diabetes 2017. Journal of diabetes research. 2018; 2018.

28. Peleg AY, Weerarathna T, McCarthy JS, Davis TM. Common infections in diabetes: pathogenesis, management and relationship to glycaemic control. Diabetes/metabolism research and reviews. 2007 Jan; 23(1): 3-13

29. Phulari YJ, Kaushik V. Study of cutaneous manifestations of type 2 diabetes mellitus. Int J Res Dermatol. 2018 Jan; 4(1): 8-13.

30. POORANA B, PRASAD PV, KAVIARASAN PK, SELVAMUTHUKUMARAN S, KANNAMBAL K. Impact of Glycaemic Control on the Pattern of Cutaneous Disorders in Diabetes MellitusA Hospital Based Case Control Study. Journal of Clinical \& Diagnostic Research. 2019 Feb 1; 13(2).

31. Pradhan S, Bhoi U. Clinical Profile of Cutaneous Manifestation in Diabetes.

32. Puri N. A study on the cutaneous manifestations of diabetes mellitus. diabetic foot. 2012 Apr 1; 2: 4

33. Ragunatha S, Anitha B, Inamadar AC, Palit A, Devarmani SS Cutaneous disorders in 500 diabetic patients attending diabetic clinic. Indian journal of dermatology. 2011 Mar; 56(2): 160.

34. Raiesi O, Shabandoust H, Dehghan P, Shamsaei S, Soleimani A Fungal infection in foot diabetic patients. Journal of Basic Research in Medical Sciences. 2018 Sep 10; 5(4): 47-51.

35. Rajagopalan S. Serious infections in elderly patients with diabetes mellitus. Clinical infectious diseases. 2005 Apr 1; 40(7): 990-6.

36. Richardson MD, Warnock DW. Fungal infection: diagnosis and management. John Wiley \& Sons; 2012 Jan 5.

37. Rosen J, Yosipovitch G. Skin manifestations of diabetes mellitus InEndotext [Internet] 2018 Jan 4. MDText. com, Inc.

38. Singal A, Grover C. Comprehensive approach to infections in dermatology. JP Medical Ltd; 2016 Feb 12.

39. Thilak S, Anbumalar M, Sneha PM. Cutaneous fungal infections in subjects with diabetes mellitus. Int J Res Dermatol. 2017 Jan; 3:558.

40. Wahid Z, Kanjee A. Cutaneous manifestation of diabetes mellitus. JOURNAL-PAKISTAN MEDICAL ASSOCIATION. 1998 Oct; 48: 304-5.

41. Wigington G, Ngo B, Rendell M. Skin blood flow in diabetic dermopathy. Archives of dermatology. 2004 Oct 1; 140(10): 124850 .

42. Bhat $P$, Dretler A, Gdowski M, Ramgopal R, Williams D. The Washington manual of medical therapeutics. Lippincott Williams \& Wilkins; 2016 Jan 11

43. Sarkany RP, Breathnach SM, Morris AA, Weismann K, Flynn PD. Metabolic and nutritional disorders. Rook's textbook of dermatology. 2010 Mar 22; 1: 1-03.

\section{Source of Support: None declared.}

Conflict of Interest: None declared.

For any question relates to this article, please reach us at: editor@globalresearchonline.net New manuscripts for publication can be submitted at: submit@globalresearchonline.net and submit_ijpsrr@rediffmail.com 